\title{
THE RIGHT TO SILENCE IN THE PRESENCE OF ANTON PILLER: A QUESTION OF SELF INCRIMINATION
}

\author{
MITCHELL P. MCINNES*
}

\begin{abstract}
The author discusses the advent of Anton Piller orders and contrasts its benefits against the right against self incrimination.
\end{abstract}

\section{INTRODUCTION}

It is 9:30 A.M. and as your client swings open his doors to usher in another profitable day in the lucrative world of video sales and rentals he is confronted by a scowling competitor, his lawyer, several large articling students and a member of the local constabulary. The lawyer, clutching a court order in his hand, tells your client, clutching his heart in his hand, that he is being "requested" to grant permission to the group to enter into his premises so that they might search for and seize materials and documents enumerated in the order. Further, the lawyer says there are a number of questions which should be answered and a number of documents which should be produced. Your client, well aware that some of his inventory is of questionable legal lineage, immediately realizes that compliance with such provisions could have dire criminal consequences. He is "consoled" with the fact that what he is being presented with is not a search warrant and that he is free to ignore it if he wishes. However, should he do so without first having the order rescinded (a task not easily accomplished even in those isolated cases where it is possible to do so'), he will likely have unfavourable inferences drawn against him in later stages of the action, and he will be liable for contempt of court even if it is subsequently determined that the order should not have been granted. ${ }^{2}$

This scenario, while admittedly melodramatic, does illustrate the remarkable nature of what are known as Anton Piller orders. The orders, which derive their name from the 1976 English Court of Appeal decision in Anton Piller KG v. Manufacturing Processes Ltd. ${ }^{3}$ have become a mainstay in the fight against intellectual property pirates in England and are beginning to make similar inroads in Canada. Their operation is truly extraordinary. A plaintiff in an intended civil action may apply ex parte and in camera for an order allowing it to enter upon the premises of another (typically, though not necessarily, a future defendant) to search for and seize materials and documents which are the plaintiff's property or which would serve as evidence in the pending suit. If satisfied, firstly, that the plaintiff has an extremely strong prima facie case, secondly, that he

- Mitchell P. McInnes is a third year law student at the University of Alberta. He will be studying at Cambridge in 1988/89 and then returning to Edmonton to article with Reynolds, Mirth, Richards and Farmer.

1. See A. Rock "The Anton Piller Order: An Examination of Its Nature, Development and Present Position in Canada" (1984) 5 Adv. Q. 191 at 202-205.

2. Anton Piller KG v. Manufacturing Processes Ltd. [1976] 1 All E.R. 799 at 783. Hereafter referred to as Anton Piller.

3. Id. While it is this decision which so spectacularly thrust the order onto the legal landscape, there are in fact earlier instances in which such injunctions were granted. See eg. EMI Ltd. and Others v. Pandit [1975] 1 All E.R. 418 (Ch.D.); Pall Europe Ltd. v. Microfiltrex Ltd. [1976] R.P.C. 32 b (Ch.D.). 
may suffer very serious damage, and thirdly, that the defendants have in their possession the incriminating documents or items, and that there is a real possibility that they may destroy such materials before an application can be made inter partes 4 , a court may issue an Anton Piller order. The essence of such an order is, of course, the element of surprise, a feature which is necessary to effectively combat intellectual property pirates ${ }^{5}$ who are typically "fly-by-night" operators capable of closing up their operation in one place and relocating in another very quickly. The primary aim of such an order is to allow the necessary evidence to be preserved until trial, thereby ensuring that the state's legal machinery is not frustrated and the courts are not left impotent by a lack of proof to affect a just result. A secondary purpose may also be to simply recover property which rightly belongs to the plaintiff, in which case the order typically acts dispositively of the issues, and not merely as interim relief pending trial.

The contents of any given order will depend upon the particular facts involved. The order granted in Anton Piller merely allowed the plaintiff to enter the defendant's premises, inspect all documents and remove those enumerated by the court. Rather unobstrusive by today's standards, the court at that time felt that it had to be taken to "the extremity of [its] power"'. (If that is true, one must wonder where the courts stand in 1988). The aim of this discussion is to examine Anton Piller orders in their most extreme form - i.e. where, in addition to the "search and seizure" provisions, the plaintiff is permitted to demand that the defendant disclose certain information and produce certain documents. More specifically, it will be asked whether such orders violate the served party's right against self incrimination in that they compel disclosure of evidence which may be used by the Crown against that party in subsequent criminal proceedings. The question will be addressed from an Alberta perspective.

That such orders are desirable in the fight against intellectual property pirates is not questioned. To simply allow a plaintiff to carry out a search and seizure exercise would, in many cases, do little to remedy the problem at hand. There may not be sufficient materials within the defendant's premises to build a strong case against him and, more importantly, the defendant will often be but one player in a large operation. In either event, the plaintiff will have ineffectively spent his one opportunity to catch the defendant off-guard. Any further proceedings are apt to be frustrated as evidence and people will likely have disappeared. However, it is submitted that in the long run the damage caused by the more intrusive orders outweighs the benefits derived. Absent a legislative change which would allow such orders to have effect without violating the defendant's privilege against self incrimination, it is suggested that such orders should not be issued.

It should be noted that this discussion will approach the issue of Anton Piller orders and self incrimination from a perspective which is decidedly

4. Anton Piller KG v. Manufacturing Processes Lid., supra n. 2 at 784 per Ormrod, L.J.

5. Although Anton Piller orders are generally spoken of in context of intellectual property law, they are theoretically available in any action. See eg. Emanuel v. Emanuel [1982] 2 All E.R. 342 (Fam. Div.), a matrimonial dispute case.

6. Anton Piller KG v. Manufacturing Processes Ltd., supra n. 2 at 784, per Ormrod L.J. 
different than that taken in most of the articles which have examined the matter'. It is respectfully submitted that most commentators have been biased by predisposition in favour of the orders, a fact which colours much of their analyses. Although it is certainly not being suggested that these works are not without merit, it does appear to be true that what is lacking in the debate is a dissenting voice. For this reason, the discussion which follows will focus more on the arguments which can be made in favour of recognizing the defendant's right against self incrimination. It should not be assumed, however, that the purpose of adopting such a stance is merely to play the role of the devil's advocate. While few would dispute that positive action must be taken to provide adequate relief for those who feel their rights are being trodden upon, there are legitimate arguments to be made against Anton Piller orders. These arguments have generally lacked a voice among Canadian scholars, and it is hoped that this discussion will have a part, however humble, in rectifying that imbalance. There is much to be said in favour of caution and vigilance where injunctive relief has the potential to deleteriously affect individual rights.

\section{SELF INCRIMINATION}

The issue of self incrimination in regards to Anton Piller orders was judicially considered for the first time by the House of Lords in the 1981 case of Rank Film Distributors Ltd. and Others v. Video Information Centre and Others ${ }^{8}$. Because of the importance of the decision and reasoning in this seminal case, it will be the starting point for discussion. From there the focus will turn to the Canadian situation, and it will be asked firstly whether there is any statutory protection available to Anton Piller defendants, and secondly whether the common law affords a basis upon which an argument in favour of a privilege against self incrimination can be made. Finally, various policy arguments for and against the recognition of a privilege will be surveyed.

\section{A. THE RANK FILM DECISION}

The progeny of the English Court of Appeal in Anton Piller was well nurtured by lawyers and the judiciary alike, and by 1981 had become a robust child indeed. Orders were being requested and granted in an ever increasing number and in ever more complex forms. Solicitors came to realize that the orders held promise for a utility far beyond what was originally envisaged. Courts were urged to take the next "logical" step and allow a plaintiff to not only search for and seize documents and materials, but to also interrogate the served party and demand that he produce documents not otherwise accessible. Some courts assented to such requests, apparently unaware that the step that they took, although perhaps logical to the plaintiffs, in fact placed them out of bounds, legally speaking. This transgression did not, however, escape the watchful eye of the House of Lords, which, in Rank Film, declared that such orders could not be granted as they violated the defendant's privilege against self incrimination.

7. See eg. D.M. Paciocco "Anton Piller Orders: Facing the Threat of Self Incrimination" (1984) 34 U.T.L.J. 26; J. Berryman "Anton Piller Orders: An Update" (1985) 2 I.P.J. 49.

8. [1981] 2 All E.R. 76. Hereafter referred to as Rank Film. 
The plaintiffs in Rank Film were the copyright holders of several movies, and the defendants were "video pirates" who made and sold copies of those same movies. Given the times, the facts all but cried out for an Anton Piller order, and in fact one was issued. As usual, the court authorized the plaintiffs (with the defendants' coerced consent) to enter the defendants' premises and seize all unauthorized copies. The order also contained more novel provisions which compelled the defendants to disclose the names and addresses of their suppliers and customers, and the location of all illicit copies and mastertapes, and to produce all relevant invoices, letters and documents. The defendants objected to these latter provisions, claiming that they violated their privilege against self incrimination. While their pleas initially fell upon deaf ears, they were successful in persuading the Court of Appeal'. The plaintiffs then appealed that decision and the matter came before the House of Lords.

The Lords begrudgingly upheld the Court of Appeal decision and found for the defendants. They unanimously felt compelled to adopt such a view as there was a real possibility that compliance with the order would render the defendants liable to criminal charges of a serious nature. It was held that unless the likelihood of prosecution was "contrived, fanciful or imagined"10, or that the potential penalties were not heavy, those provisions which compelled self incrimination had to be expunged. On the facts before them it was obvious to the Lords that the defendants, if forced to comply with full order, could be subject to criminal prosecution under section 21 of the Copyright Act, section 18 of the Theft Act and under the common law offence of conspiracy to defraud. While the maximum penalty of $£ 50$ under the Copyright Act was considered trivial, and the likelihood of prosecution under the Theft Act too remote to warrant recognition of the privilege against self incrimination, the common law offence fit the bill on both counts. The result was that the plaintiffs were unable to access the other conspirators through the defendants. Their action would have at most a minimal impact on the overall pirate operation.

The situation moved Lord Denning to quote W.S. Gilbert: "It is, it is a Glorious thing, to be a Pirate King." Indeed, the law as it stood after the Lord's decision did seem rather paradoxical. The more criminal a defendant's conduct, the less a court in a civil matter could do. Such a situation was clearly advantageous to those very people who were the most responsible for the escalating problem of video piracy, and who were the most difficult to prosecute. Fortunately, the English Parliament paid heed to the dismay expressed by the House of Lords, and enacted section 72 of the Supreme Court Act of $1981^{12}$ which denies defendants in intellectual property disputes any privilege against self incrimination. In its stead the legislation provides them with statutory protection by declaring that evidence obtained pursuant to Anton Piller orders is inadmissible in subsequent criminal proceedings.

9. [1980] 2 All E.R. 273.

10. Rank Film Ltd. v. Video Information Centre, supra n. 8 at 80 .

11. WEA Records Ltd. v. Visions Channel 4 Ltd. [1981] 1 W.L.R. 721.

12. Supreme Court Act, 1981 (U.K.) c. 54. 
The issue for present purposes is, of course, whether or not Rank Film should be followed in Canada. Obviously decisions of the House of Lords, while perhaps persuasive, are not binding on Canadian courts. The question being asked is whether the reasoning employed by the Lords should yield a similar result in this country, taking into account the differences between the legal systems. To dismiss the Rank Film decision as an unfortunate episode in the history of Anton Piller is one thing. To deny a person the privilege against self incrimination (if, in fact, it is legally justified) merely because it causes inconvenience or even hardship to a plaintiff in an intellectual property dispute is something else altogether.

\section{B. INAPPLICABILITY OF THE CHARTER AND THE EVIDENCE ACTS}

There is no question of the ability of a plaintiff in a civil action to compel a defendant to disclose incriminating evidence. Section 5 of the Canada Evidence Act ${ }^{13}$, section 6 of the Alberta Evidence Act ${ }^{14}$ and section 13 of the Canadian Charter of Rights and Freedoms's permit this. However, the defendant, while perhaps reluctant to comply for fear of losing the suit, need not concern himself with the criminal ramifications arising from disclosure. The reason for this is that the sections also provide that any evidence so obtained is inadmissible in other proceedings. (The Evidence Acts have such an effect only if the disclosing party objects to the questions.) Unfortunately, by issuing an Anton Piller order, a court introduces a unique timing element which has the result of denying the served party any statutory protection. The provisions of the Charter and the Evidence Acts are, unlike section 72 of the U.K. Supreme Court Act 1981 , inapplicable to Anton Piller situations.

The Charter and Evidence Acts protect "witnesses", a term which does not apply to a party in the type of scenario described at the beginning of this discussion. A brief survey of the authorities which have defined the term make this clear. Section 1(c)(i) of the Alberta Evidence Act states that "witness" includes a person "who in the course of an action is examined orally on discovery ...". Although Anton Piller orders have on occasion been likened to the discovery process ${ }^{16}$, it is submitted that such an analogy is unsound and should be rejected. "Discovery" in the context of civil suit is used as a term of art to describe the formal process which occurs after pleadings have been exchanged and which is governed by certain rules, many of which are not observed in an Anton Piller situation.

McRuer C.J.H.C., in the course of examining section 5 of the Canada Evidence Act, defined the term "witness" as one "lawfully giving evidence under a properly constituted legal tribunal which has the power to take evidence under oath.'16A Time proved the Chief Justice's definition to be accurate as the same ideas were later echoed by the Supreme Court of

13. R.S.C. 1970 , c. E-10.

14. Alberta Evidence Act, R.S.A. 1980, c. A-21.

15. Canadian Charter of Rights and Freedoms, Constitution Act, 1982, as enacted by Canada Act 1982 (U.K.) 1982, c. 11.

16. "The Anton Piller Order: An Examination of Its Nature, Development and Present Position in Canada" supra n. 1 at 207.

16A. R. v. Lunan [1947] O.R. 201 (C.A.). 
Canada in Klein v. Bell ${ }^{17}$ and DiIorio v. Warden, Jail of Montreal and Brunet ${ }^{18}$. Taken together those cases set out the three elements included in Chief Justice McRuer's definition: (i) the giving of "evidence", (ii) under a legal tribunal or other similar setting, (iii) by one under oath. As Paciocco has noted ${ }^{19}$, these criteria are not met in an Anton Piller situation. While it may be argued that what would be provided is "evidence", it is doubtful that the disclosure would arise in the appropriate setting. Only upon a perverse reading of the courts' words could the events in question be said to occur "under a properly constituted legal tribunal" or "in the course of [a] judicial proceeding" confused and disorganized. Finally, it is undeniably clear that a party being served with an Anton Piller order would not be under oath or affirmation.

\section{THE COMMON LAW PRIVILEGE IN CANADA}

The privilege against self incrimination had by the 17th century become firmly entrenched as one of the fundamental principles of the common ${ }^{1 a w^{2}}$. However, while venerated elsewhere, it has at times been treated rather rudely in Canada, and there are those who suggest that its availability in this country is restricted to the provisions in the Evidence Acts and the Charter, and to the right of the accused in a criminal trial to refuse to take the stand ${ }^{23}$. Because this view has been espoused by such eminent authors as Ratushny, and has found favour in several appellate court decisions $\mathrm{s}^{24}$, it cannot be dismissed lightly. It is respectfully submitted, however, that given the persuasive arguments to the contrary, the issue must at the very least be taken to be unsettled.

\section{(a) Does the common law apply in Canada today?}

The most logical pattern to follow in searching for a common law privilege in current Canadian law is to ask firstly whether it ever did exist, and secondly whether it has ever been done away with. It is submitted that these questions should respectively be answered in the affirmative and in the negative.

It is clear that the privilege against self incrimination was part of the English law received in the North West Territories (including what is not Alberta) as of 15th July $1870^{25}$. Within the Canadian context a basic principle, as articulated in Sweezy v. Crystal Chemicals $L t d .{ }^{26}$, is that a

17. [1955] 2 D.L.R. 513.

18. (1976) 73 D.L.R. (3d) 491.

19. "Anton Piller Orders: Facing the Threat of Self Incrimination", supra n. 7 at 30.

20. Klein v. Bell, supra n. 17 at 520.

21. Dilorio v. Warden, Jail of Montreal and Brunet, supra n. 18 at 538.

22. For a history of the privilege against self incrimination see: Levy, Origins of the Fifth Amendment (1968, Oxford); 8 Wigmore, Evidence (McNaughton Rev.), s. 2250; Delisle, Evidence (1984 Carswell).

23. Self Incrimination in the Canadian Criminal Process (1979); "Is There a Right Against Self Incrimination in Canada" (1973) 19 McGill L.J. 1.

24. See eg. R. v. Sweeny (No. 2) (1977) 35 C.C.C. (2d) 245 (Ont. C.A.); Summa Corp v. Meier (1981) 30 B.C.L.R. 69 (B.C.C.A.).

25. See Klein v. Bell, supra n. 17.

26. (1963) 50 M.P.R. $3 c$ at 33-34 (N.S. S.C. App. Div.). 
common law privilege can be abrogated or curtailed only by legislation couched in clear and explicit terms. This has not been done. While it may be argued that the provisions of the Evidence Acts have that effect, such a position is untenable in light of the Supreme Court of Canada's decision in Klein v. Bell ${ }^{27}$. The facts involved were roughly analogous to those which might today be found in an Anton Piller case. In the course of a civil action the appellants were requested on discovery to answer certain questions and to produce certain documents. Fearing that compliance would have an incriminating effect the appellants refused, arguing that section 5 of the British Columbia Evidence $\mathrm{Act}^{28}$ was inapplicable, and that it was therefore open to them to rely on the common law privilege. The Supreme Court agreed. Kerwin C.J.C., found the provisions of the provincial Act to be ultra vires in that they purported to govern the admissibility of evidence in federal trials. He then added that "[in] the absence of any such remedial legislation the common law applies .....29 As a result the defendant was permitted to insulate himself with the privilege against self incrimination.

Also noteworthy is the fact that Rand J., held that the privilege extended to documents as well as to oral statement $\mathrm{s}^{30}$. Such a finding is in accord with earlier case law ${ }^{31}$ and is, of course, highly relevant in the context of the present discussion. One of the offensive features to the order in Rank Film involved the production of documents.

It is submitted that the ratio in Klein v. Bell supports the contention that the privilege against self incrimination should be available to one served with a Anton Piller order which demands the disclosure of incriminating information and documents. Whether the provisions of the Evidence Acts are inapplicable because they are ultra vires or because they simply are not broad enough to cover a given situation, the result is the same. Only where legislation explicitly applies will the common law privilege be abrogated or curtailed. In all other instances the common law lies beneath the legislative patchwork, immediately available where there is a statutory gap, and waiting in abeyance where the legislation does apply.

(b) To whom does the common law privilege apply?

To simply affirm that the common law privilege against self incrimination does exist is, however, insufficient. One must also ask of the circumstances in which it applies. A strong argument can be made against its availability to an Anton Piller defendant on the basis that only statements made in the course of judicial proceedings are protected. The Supreme Court of Canada decision in Marcoux and Solomon v. The Queen ${ }^{32}$ seems to support such a view. Dickson J. (as he then was), stated that "the privilege extends to the accused qua witness and not qua accused", and that the concern was only with "testimonial compulsion

27. Supra n. 17.

28. Evidence Act, R.S.B.C. 1948, c. 113.

29. Supra n. 17 at 315.

30. Supran. 17 at 320.

31. Hunnings v. Williamson (1883) 10 Q.B.D. 459.

32. [1976] 1 S.C.R. 763, 60 D.L.R. 119, (1975) 24 C.C.C. (2d) 1. 
specifically and not with compulsion generally" ${ }^{33}$. If this is so, then it is clear that an Anton Piller defendant at the time when he is served with the order cannot avail himself of the privilege as he is not yet a "witness".

It is submitted, however, that there has been a trend towards a more liberal application of the privilege over the past decade - a trend which in 1986 was reflected in a majority decision of the Supreme Court of Canada $^{34}$. In 1978 that court, as it had in Marcoux and Solomon, addressed the question of self incrimination in the context of extra judicial statements. The accused in $R$. v. Rothman ${ }^{35}$, after explicitly refusing to make any statements to the police, was placed in a cell with an officer who held himself out to be a fellow prisoner. In the course of conversation several incriminating statements were made and the issue of whether those statements could be introduced into evidence came before the Supreme Court. Once again the majority held that the privilege against self incrimination was available only for witnesses, and accordingly found the statements to be admissible.

However, in a strong dissent Estey J., noted the injustice which flows from such a view. It in effect permits that which the privilege is intended to prohibit. While the authorities may not compel an accused to testify against himself in court, they may introduce as indirect evidence extra judicial comments obtained through deception, which he made after having expressed a clear desire to not make any statements to the police. In such a case the effect would be the same as if he had been forced to testify against himself in court, and the purpose of granting the accused a privilege qua witness would be lost. In the context of an Anton Piller case the situation is, if anything, even more striking in that the statements are extracted through blatant coercion (in the form of the threat of contempt charges) rather than through deception.

Dubois v. The Queen ${ }^{36}$, a 1986 decision of the Supreme Court of Canada, further illustrates the judicial trend towards a more liberal view of the applicability of the privilege against self incrimination. At trial the accused chose to take the stand, thereby precluding himself from claiming the privilege. On appeal, however, it was found that the trial judge had made several misdirections and a re-hearing was ordered. Apparently desirous of a new line of defense the accused attempted to have his testimony from the first trial excluded from evidence on the basis that its use would violate his right not to incriminate himself. Mr. Justice Lamer, speaking for the majority, adopted a very generous view in regards to the privilege and ruled in favour of the accused. By interpreting it in light of sections 11(c) and (d) of the Charter, and the fact that the evidentiary burden was on the Crown, Lamer J., held that section 13 of the Charter should be read as protecting the accused from being indirectly compelled to incriminate himself. "To allow the prosecution to use . . . the accused's

33. Id. at 60 D.L.R. 123, 24 C.C.C. (2d) 5 .

34. Infra, Dubois v. The Queen (1986) 23 D.L.R. (4th) 503, 22 C.C.C. (3d) 513,48 C.R. (3d) 193.

35. R. v. Rothman (1978) 121 D.L.R. (3d) 578, 59 C.C.C. (2d) 30, 20 C.R. (3d) 97.

36. Supra n. 34. The author wishes to acknowledge A. Whitten "The Privilege Against Self Incrimination" 29 Crim. L.Q. 66 at $86-87$ as a source of some of the observations relating to this decision. 
previous testimony would, in effect, allow the Crown to do indirectly what it is estopped from doing directly by s.11(c), i.e., to compel the accused to testify." ${ }^{37}$

Notwithstanding these noble views, Mr. Justice Lamer was still faced with the fact that section 13 of the Charter, upon which his decision rested, would apply only if the retrial could be characterized as "another proceeding" vis a vis the first trial. Mr. Justice McIntyre, in a dissenting opinion, was quite likely correct in stating that such a characterization would artificially fragment the judicial process and would be possible only upon an unfair reading of the section. Lamer J., however, did choose to so characterize the retrial, a decision which, as Whitten has observed ${ }^{38}$, was probably prompted more by a desire to achieve a fair result than by a proper legal analysis of what would constitute "another proceeding".

Admittedly, the Dubois decision can't be cited as conclusive authority for the proposition that extra judicial statements can be the subject of the privilege against self incrimination. It is submitted, however, that the decision does illustrate an increased concern for the privilege and a liberalization of its availability. Further, there seems to be no just basis for distinguishing the type of statements involved in Dubois from the extra judicial statements which would arise in an Anton Piller case. Just as it would be unfair to hold the testimony from an earlier trial admissible as indirect evidence, so too, it would be unfair to allow statements coerced through a fear of contempt charges to be introduced into evidence. In both instances the statements would act as the equivalent of the direct testimony which could not be compelled. At any rate, the recent, post-charter holdings by the Supreme Court do seem to call into question the earlier, harsher views concerning the privilege against self incrimination, such as those expressed in Marcoux and Solomon. Some lower courts have recognized this shift and have begun to act accordingly ${ }^{39}$. The future in this area seems somewhat uncertain at the moment and while the earlier case law will provide a formidable obstacle to Anton Piller defendants, it does appear possible to persuasively argue that the privilege should be available to such parties. Indeed, on the basis of the policy arguments which will be examined next, it would appear that the courts should strive to affect such a result.

\section{ARGUMENTS IN FAVOUR OF THE PRIVILEGE}

Several arguments in favour of the privilege have already been made during the discussion. Some have been fully explained and would not benefit from repetition. Those arising out of Mr. Justice Estey's dissent in Rothman are an example. Others, however, merit further attention. And finally, there is a third group of arguments which have yet to be addressed.

While the Evidence Acts and section 13 of the Charter are not directly applicable, it is submitted that they are not altogether irrelevant. From their provisions certain policy concerns may be gleaned. It seems clear that

37. [1971] S.C.R. 272, 11 D.L.R. (3d) 673, [1970] 4 C.C.C. 1.

38. Supra n. 34 at 88.

39. See eg. R. v. Esposito (1986) 53 O.R. (2d) 356 (Ont. C.A.), 24 C.C.C. (3d) 88, 49 C.R. (3d) 193. 
their primary purpose is to promote a fuller airing of the facts and issues which arise in a given dispute. In order to achieve this it was necessary to remove the common law privilege against self incrimination. But it also seems clear that the drafters recognized that it would be unfair, and perhaps naive, to expect compliance with the legislation if it would potentially result in criminal liability. The provisions could easily have been made without the guarantee of protection vis a vis other proceedings. That they were not, it is suggested, illustrates that there was a policy among the drafters of the Charter and the Evidence Acts to uphold the honourable tradition of not compelling a person to incriminate himself.

It must be seriously questioned whether this policy should be disregarded simply because a party to a civil action has taken an extraordinary step. Should a plaintiff in an Anton Piller situation have the ability, by applying for an order ex parte and in camera, to limit the rights of the party who is served? Should a person, because of events which he is unaware of and over which he has no control, be forced to incriminate himself in circumstances which, if the usual procedures were followed, he would be protected? Should a person who is involved in a proceeding which, owing to its recent development, could not have been contemplated the drafters of the Evidence Acts, be denied the protective shroud which that legislation normally affords to one in his position? The answers to these questions seem obvious.

Admittedly, those served with the orders are not likely to be model citizens who faithfully observe every law. (Indeed, if they were there would be nothing in regards to which they could incriminate themselves). However, one must ask whether their activities are so heinous and so repugnant to public sensibilities that they should be denied a basic right which is given to every other criminal. It is submitted that in the absence of legislation similar to section 72 of the U.K. Supreme Court Act, the courts should refrain from issuing Anton Piller orders which potentially expose those served to lengthy prison terms ${ }^{40}$. Ex parte interlocutory proceedings in a civil suit should not have the ability to be the determinative factor in subsequent criminal proceedings.

As Anton Piller orders begin to appear with greater regularity in Alberta it is inevitable that concomitant with the increased familiarity will come a decreased concern for detail on the part of some lawyers. No longer intimidated by their novelty, some will also feel bold enough to abuse the orders. Granted, there are procedural safeguards that a court may require a plaintiff to agree to, such as an undertaking in damages, a promise to have the order personally served by his solicitor, etc. The point being made, however, is that there will always be those lawyers who will try to avoid the strict requirements of the law so as to further their interests and those of their clients. The English courts have already begun to encounter intentional abuses of Anton Piller orders ${ }^{40 \Lambda}$ - it is difficult to believe that the scruples of Canadian lawyers are so superior to those of their British

40. See IV. Potential Criminal Penalties for a discussion of penal sanctions which an Anton Piller defendant may be subject to.

40A. Rt. Hon. Peter Oliver "Anton Piller. The Civil Search Warrant" 1983 Cambridge Lectures 68 at 75. 
counterparts so as to preclude similar incidences in this country. Under normal circumstances such abuses would be unfortunate but rectifiable occurrences. In the context of Anton Piller orders which compel the served party to disclose potentially incriminating information, the consequences may be far more serious.

Consider a scenario in which the served party, legally unsophisticated, contacts his lawyer only after having complied with the plaintiff's demands. Suppose further that the lawyer is subsequently successful in persuading the issuing court that it had been misled by the plaintiff, and that the order was wholly unjustified. The fact remains that the statements made by the served party are irretractable. If they have fallen into police hands they may be used in a criminal prosecution regardless of the fact that their disclosure was compelled by an improperly obtained order. Thus, because of the potential effect, the abuse of Anton Piller orders is far more harmful than is the case with other forms of interlocutory relief. In most instances an award of damages against a party who acted improperly in securing an injunction is sufficient to remedy any injury which may have been sustained. Where damages would not be adequate, such as in the case of mandatory interlocutory injunctions, the courts are generally most reluctant to grant an order ${ }^{208}$. In the case of Anton Piller orders that reluctance should amount to a refusal.

The situation seems even more intolerable when it is realized there is nothing which a court issuing an Anton Piller order can do to prevent such events from transpiring. Regardless of how stringent the pre-requisites are to the granting of an order, it is inevitable that some applications which are not bona fides will meet with success. Futher, while section 13(2) of the Judicature Act would allow a court to issue an order with a condition attached which prohibited the plaintiff from using the information obtained for any purpose other than that which is stated, it is obvious that the court could not similarly restrain the Crown ${ }^{4}$.

To suggest that the defendant would be protected in subsequent criminal proceedings through the exercise of judicial discretion is naive and probably incorrect. The Supreme Court of Canada in $R$. v. Wray ${ }^{42}$ greatly narrowed the ambit of judicial discretion, stating that it could only be exercised where the admission of evidence would operate unfairly. Evidence which might operate unfortunately for the accused is, by itself, not enough to allow a court to refuse to receive it. ${ }^{43}$

It is only the allowance of evidence gravely prejudicial to the accused, the admissibility of which is tenuous, and whose probative force in relation to the main issue before the court is trifling which can be said to operate unfairly.

It is doubtful whether information obtained pursuant to an Anton Piller order would be held to satisfy all of these requirements. For example, it would be difficult to characterize the records of a defendant which clearly showed him to be dealing in pirated videotapes as trifling in relation to the main issue of whether he was infringing upon the rights of the person who owns the copyright to the movies.

40B. See eg. Shephard Homes Ltd. v. Sandham [1971] Ch. 340, [1970] 3 W.L.R. 348, [1970] 3 All E.R. 402, 21 P. \& C.R. 863, 114 S.J. 636.

41. Rank Film Ltd. v. Video Information Centre, supra n. 8 at 81 .

42. [1971] S.C.R. 272, 11 D.L.R. (3d) 673, [1970] 4 C.C.C. 1.

43. Id. at [1971] S.C.R. 293. 


\section{POTENTIAL CRIMINAL PENALTIES}

Even if a court should decide that the privilege against self incrimination is theoretically available, it may still deny it in practice if the pre-requisites in Rank Film are not met. Specifically, the court would have to be satisfied that there was a real possibility that the information obtained pursuant to the order would tend to expose the disclosing party to a serious charge which, if proved, would attract a heavy penalty.

One who violages intellectual property rights in Canada is potentially subject to a great range of charges depending upon the facts involved. What exactly would be required to satisfy the Rank Film test is, of course, a matter of opinion to be answered by the courts. However, it is unlikely that the penalties imposed under the Patent $\mathrm{Act}^{44}$, the Copyright Act ${ }^{45}$, the Competition $\mathrm{Act}^{46}$, or the Industrial Design $\mathrm{Act}^{47}$ would warrant the recognition of the privilege. Section 338 of the Criminal Code ${ }^{48}$, on the other hand, provides that one guilty of fraud where the value of the subject matter exceeds two hundred dollars is liable for imprisonment for up to ten years. Sections 364 to 372 deal more specifically with the forgery of trademarks and trade descriptions and are punishable by summary conviction, or by indictable of fence, in which case the maximum penalty is two years imprisonment. Clearly, it would be proper to characterize such lengthy prison terms as "serious". What is potentially at issue for a party served with an Anton Piller order, then, is his liberty.

\section{v. CONCLUSION}

That Anton Piller orders are generally a positive development in the law relating to intellectual property rights is not disputed. That such orders, if they are to be effective, must include provisions which compel the served party to disclose information and produce documents is similarly admitted. However, it is submitted that the potential harm which may result is disproportionately great in comparison with the benefits which are derived.

It has been argued that absent the provisions of the Charter and the Evidence Acts, which would typically protect one in the position of an Anton Piller defendant, the common law privilege against self incrimination does apply. It has also been argued that the policy concerns inherent in the Charter and the Evidence Acts support a view. In view of this, to present a party with the choice between self incrimination and contempt of court charges clearly seems improper.

The most desirable situation is, of course, to allow effective Anton Piller orders to be made and at the same time protect the served party from subsequent criminal ramifications which could result from the disclosures.

44. R.S.C. 1970, c. P-4, s. 78(a): maximum penalty of $\$ 200$ fine and/or 3 months imprisonment.

45. R.S.C. 1970, c. C-30, s. 25 : maximum penalty of $\$ 200$ for first of fence.

46. R.S.C. 1970, c. C-23, as amended, s. 36(5).

47. R.S.C. 1970 , c. $1-8$, s. 16 : maximum penalty of $\$ 120$ recoverable by the proprietor of the design.

48. R.S.C. 1970 , c. C.34. 
The U.K. Supreme Court Act of 1981 illustrates how these dual goals can be achieved. Until similar legislation is enacted in Canada the courts will be forced to choose between providing strong interlocutory relief for plaintiffs in civil actions and protecting against the danger of compelling self incrimination. Of the two, the latter is the more important concern. 